\title{
Measuring the perceived e-retailing websites innovativeness and their effects on supply chain performance
}

\author{
Anas A. Salameh ${ }^{\mathbf{a}^{*}}$ \\ Al-Kharj 11942, Saudi Arabia

\begin{tabular}{l}
\hline C H R O N I C L E \\
\hline Article history: \\
Received January 2, 2020 \\
Received in revised format June \\
8,2020 \\
Accepted July 172020 \\
Available online \\
July 172020 \\
\hline Keywords: \\
E-retailing \\
Websites innovativeness \\
Perceived e-retailing websites \\
innovativeness \\
Supply chain performance
\end{tabular}

${ }^{a}$ Assistant Professor, Department of Management Information Systems, College of Business Administration, Prince Sattam bin Abdulaziz University, 165

\section{A B S T R A C T}

Digital development transformation and rapid dissemination of technological innovations, has let various e-retailers site make an advanced investment to get the benefit of the latest business opportunity for building innovations. Thus, this study identifies the main effect of perceived eretailers websites innovativeness on supply chain performance, functional competences, perceived self-congruence, customer hope, perceived service advantages, word of mouth behavior, and hedonic value. Data used in this study were collected from banking customers who own a visa card that allows them excute an online payment and the sample was tested on the analysis model using (SEM-PLS) tool. The results of the study support that e-retailers' website innovativeness was positively associated with the constructs of each innovation factor. The given analyses supervise practitioners for better management of e-retailers website innovation implementation along with the supply chain performance.

(C) 2020 by the authors; license Growing Science, Canada.

\section{Introduction}

Innovation is essential for all organizations because it assists in gaining new customers and keeping existing ones (Salameh, Ahmad, Zulhumadi, \& Abubakar, 2018). Unfortunately, many innovations failed within the first three years of their startup in the market (Dougherty, 1992). To make sure that innovations will succeed in the future in the marketplace, a consumercentral perspective is fundamental (Kunz, Schmitt, \& Meyer, 2011). the ultimate consumer is the one who determines the success of any innovation. Expert-based views of innovation often fail to present solutions or find patterns for consumer needs because often both consumers and experts might view or deal with innovations with a different point of view (Rogers \& Shoemaker, 1971). The development of communication and information technologies (e.g., Web 2.0 applications and platforms) that was delivered throw the website interface helped in the creation of new services brand experiences which enable bigger control, individualization and interaction in the e-retails shopping environment (Cho \& Menor, 2010; Davis, Buchanan-Oliver, \& Brodie, 2000; Hausman \& Siekpe, 2009). Therefore, telecommunication and mobile organizations always try to expand their services and products presented by mobile phones (i.e. mobile payment, mobile social media, mobile internet, mobile learning, mobile shopping, mobile commerce, and mobile government) (Alalwan, Baabdullah, Rana, Tamilmani, \& Dwivedi, 2018; Alkafagi, Salameh, \& Abu-AlSondos, 2019; Gerpott \& Meinert, 2016; Laukkanen, 2016; Rana, Dwivedi, Williams, \& Weerakkody, 2016; Salameh \& Hassan, 2015; Shareef, Baabdullah, Dutta, Kumar, \& Dwivedi, 2018; Xu, Thong, \& Tam, 2017). Experts may look at innovations only from a functional or technical viewpoint, while consumers might be concerned whether the company's offers suit their lifestyle preferences and create new experiences for them (Danneels \& Kleinschmidtb, 2001; Schmitt, 1999). The perception value of consumer expertise is essential for product technology, but there have been few discussions about the innovativeness perception of the customer of the websites being considered (Hong, Lin, \& Hsieh, 2017). Some marketing research has presented a consumer-central

* Corresponding author

E-mail address: a.salameh@psau.edu.sa (A. A. Salameh)

(C) 2020 by the authors; licensee Growing Science. doi: 10.5267 j.uscm.2020.7.003 
opinion, focusing mostly on customers' perceptions of new products (Hoeffler, 2003). Innovation is broadly seen as a crucial component of competitiveness, rooted in the e-retailer website structures, processes, products, and services. In this research, customer innovativeness is considered as a major variable affecting customer perceptions. The existing research aims to examine customer innovativeness and their impact on perceived self-congruence, customer hope, perceived service advantage, and word of mouth behavior, so that will help e-retailers website to present successful services and products on their websites in the future.

\section{Literature Review}

\subsection{Innovativeness and its impact on supply chain performance}

The study of Bellamy, Ghosh, and Hora (2014); Zimmermann, Ferreira, and Moreira (2016) reviews numerous innovation issues and their connections with the supply chain perspectives. The innovation enforcement practices affect supply chain structure and can be used as a method of supply chain reengineering (Blackhurst, Wu, \& O'Grady, 2005). Furthermore, it affects the performance of the supply chain in terms of the cost of direct production and overheads, times of delivery, and inventory levels (Crippa, Larghi, Pero, \& Sianesi, 2010).

The innovation practices enforcement is viewed as a fundamental factor in supply chain management (Gabdullina, Amanbayeva, Zeinullina, Tlessova, \& Azylkanova, 2020). Organizations need to deal with technological innovations introduction (e.g. augmented reality, Internet of Things, and additive manufacturing), which needs the minds to move on how the supply chain is considered and how to manage its functions. Marsillac and Roh (2014) propose that good innovation is usually conducted by the innovation process as goods modifications/ changes expect that the process of delivering the goods must additionally undergo modifications. Marsillac and Roh (2014) exhibit the case of an organization that changed its configuration of supply because it launched new goods and transformed its raw elements. In contradiction, the conclusions of Arlbjørn, de Haas, and Munksgaard (2011) present that despite the large enforcement of innovation practices with the supply chain, few companies make adjustments to the construction of their supply chain network.

Some practitioners regard the determinations about innovation practices to be with the principal choices in designing/ redesigning the supply chain. Fisher (1997); Payne and Peters (2004) recommend configuring of supply chain based on the level of goods innovativeness. Hence, the initial step in configuring a supply chain is to resolve whether the good is functional or innovative. Furthermore, Burgess and Gules (1998) examine supply network design like relationships of suppliers when the organization begins on adopting advanced technologies. Gan and Grunow (2013) investigated the diversity in creating supply chains based on whether or not they present an innovative good.

Innovation practices enforcement with supply chain barriers can be viewed as a business networkability (Arlbjørn \& Paulraj, 2013; Gabdullina et al., 2020). An organization that can innovate should be able to handle complicated supply chains to present its innovative goods strongly to the store (Gan \& Grunow, 2013). According to Holahan, Sullivan, and Markham (2014), new improvement is a core competence of an organization. This type of thinking brings awareness to the appropriation of innovation practices within an organization to expand its market share, therefore improving their profitability. In this research, e-retailer website innovativeness seems to have a strong influence on supply chain performance, further study needs to be considered for getting a better understanding of the correlation among both constructs.

\subsection{Research contents and hypotheses}

\subsubsection{Research model development}

\subsubsection{The effect of PERI in functional competence}

They evaluate innovativeness as a favorable characteristic of the firm, and this should lead to a positive evaluation (Niedrich \& Swain, 2003). Based on cue utilization theory, specific features of the target object can become a cue for other characteristics of the target, if they have confirmation and predictive value (Olson, 1977). Moreover, previous empirical studies have shown that customers depend on associations to understand specific features when particular information is lost (Brown \& Dacin, 1997; Gürhan-Canli \& Batra, 2004). For example, a corporation name can be a sign of company features such as trustworthiness and goodness (Walsh \& Beatty, 2007; Zinkhan, Ganesh, Jaju, \& Hayes, 2001). PERI might be a cue for other features. Because the innovative e-retailers sites have a "track record" of significative and successful solutions over time, customers may understand that the e-retailers may be eligible for performing all tasks sufficiently. Furthermore, previous research has shown that the innovativeness of e-retailers and plausible business competence is related (Chou, Chuang, \& Shao, 2016). Therefore, we describe functional efficiency as the customers' belief that the e-retailers have the skills to execute the work effectively and reliably (Kolesar \& Galbraith, 2000). Therefore;

Hypothesis $1\left(\left(\mathrm{H}_{1}\right)\right)$. PWI is positively correlated with functional competence. 
Based on ELM (Petty \& Cacioppo, 2012), the scope to which individuals are detailed onto a message is set by their motivation to process the obtainable information. Regarding service/ product acceptance, PERI may avail as a replacement for perceived utility and motivation (Fu \& Elliott, 2013). When consumers recognize the service as innovative, which might be affected by many aspects of service innovation, he/she promotes excitement and entertainment while thinking of it, thus, it works as a stimulus to widen the innovation.

The unique portion established in service shows the possibility of symbolic and functional values to the consumers (Fu \& Elliott, 2013). These symbolic and functional elements that are indicated through innovative service provided are the fundamental reasons customers adopt services/products (Castaño, Sujan, Kacker, \& Sujan, 2008). If the service is eligible to trigger entertainment and excitement in consumers' thinking processes, they will cognitively understand the information in a more effective way. when the consumers are motivated due to symbolic aspects, they will use the peripheral "environmental" route, which includes effective links symbolic attributes; (Cialdini, 1984). This will drive the consumers to compose self-congruity, i.e. to estimate the similarity between self-concept and their stereotypic patron image (also called self-congruity). Self-congruity plays a significant part in patronage behaviors and valuations service (Sirgy \& Su, 2000). Peripheral-route inducement may happen even with weak arguments and/or low enrollment likelihood (Petty \& Cacioppo, 1996). However, if the excuses are very powerful, consumers operate the information through the central route (it based on the scope to which consumers have the ability and stimulus to examine service-relevant information). This leads to shape or creates functional congruity, which, in turn, is the result of elaboration in the central route by estimating the utilitarian characteristic of services (Kang, Tang, \& Lee, 2015). Therefore;

Hypothesis $2\left(\left(\mathrm{H}_{2}\right)\right)$. PWI is positively correlated with the perceived self-congruence.

\subsubsection{The effect of PERI in customer hope}

Innovation has been underlined as a critical basis for market-based advantage and sustainable website services growth (Vincent, Bharadwaj, \& Challagalla, 2004). While innovation is a wide topic and has been considered differently over the marketing, entrepreneurship disciplines and management of this study concentrates on consumer-perceived e-retailers innovativeness, which is defined as consumers' perceptions of retailers with exclusive features of value (Alexander \& Van Knippenberg, 2014; Shams, Alpert, \& Brown, 2015). Based on the growing global online marketplace (Rosqvist \& Hiselius, 2016) and the existence of familiar online consumers, advanced e-retailers sites invest a massive amount of resources to improve consumers' perceptions of their categories brands as innovative (Colton, 2012). Prior studies present that consumers usually buy innovative brands to create social identity, presenting their status, and gaining other social goals (Perry-Smith \& Mannucci, 2017). E-retailers' innovativeness provides the unique features of service or products that are workable to the consumers. Based on an online purchaser's perspective, this novel characteristic denotes the possibility of gaining goal-congruent outcomes. Therefore, online marketing strategies that derive the possibility of goal-congruent innovations in an e-retailers brand may motivate customers prospects for gaining a goal, such as positioning oneself as a technology-savvy individual. underline the positivity of the customer-brand relationship, (Fournier \& Alvarez, 2013) create a theory of emotion appraisal (Roseman, Spindel, \& Jose, 1990). Emotions appraisal theory proposes that consumers' perceptions of self-caused positive experiences spur positive emotional responses such as glory and confidence. otherwise, other-caused positive experiences may drive to positive emotional responses such as thankfulness and hope (Roseman et al., 1990). In the situation of a firm's relationship with an online market, consumers' understanding of the innovativeness of a corporate brand is probable to impact their goal-directed energy, demanding customers to extend pathways to achieve a satisfactory purchasing (Fazal-e-Hasan, Ahmadi, Kelly, \& Lings, 2019). If the online buyer discovers the innovative brand novel and is eligible to fulfill their goal-oriented outcomes, they are likely to experiment hope for gaining their goals. Therefore, we hypothesize that:

Hypothesis $3\left(\left(\mathrm{H}_{3}\right)\right)$. PWI is positively correlated with the customer hope in online purchases.

\subsubsection{The effect of PERI in perceived service advantage}

Based on the material-based route, customers' value creation that follows up the material-based route might be derived from the perceived material side, such as greater service quality or distinction of the new service (Schmitt, Brakus, \& Zarantonello, 2015). Examine a new service like X E-retailer's new pickup service in which customers can take advantage of a unique service using the $\mathrm{X}$ app and pick up their orders at a chosen time at home. If this new service is particular to $\mathrm{X}$ and cannot be acquired by other retailers, then customers will recognize $\mathrm{X}$ as a retailer who has a greater service advantage. Thus, if the customers have a perception of higher service innovativeness from a retailer, then they will moreover perceive a retailer's advantage to provide a higher level of service than from market competitors (Kaleka, 2011; Lusch, Vargo, \& O'brien, 2007). Perceived e-retailer innovativeness (PERI) can provide the fundamentals of advantage because of perceived service advantage (PSA) mirror customers' perceptions of a retailer's capability to differentiate itself from others depending on their services. Therefore, the current study foresees a positive influence of PRSI on perceived service advantage (PSA). Therefore; 
Hypothesis $4\left(\left(\mathrm{H}_{4}\right)\right)$. PWI is positively correlated with the perceived service advantage.

\subsubsection{The effect of PWI in the word of mouth behavior}

Creating positive word-of-mouth (WoM) is one of the most significant marketing tools, it proposes that this form of communication has a huge impact on customers' choice than other structure of communication (Day, 1971; Godes \& Mayzlin, 2004). Although a study in WoM in e-retailing has given growing concern (Davis \& Khazanchi, 2008; Lee, Park, \& Han, 2011), there have been few empirical studies into the factors that 'spark' WoM behavior especially arising from customer experiences observed via the corporation website interface in service encounter in e-retailing. WoM is believed to play a greater important role in services settings than in goods due to specific features of services such as nonstandardization and intangibility, consumer integration within service delivery manner, all of which add to greater risk understanding of customers before using the service (Zeithaml, Berry, \& Parasuraman, 1996). In such circumstances, information from other consumers gains in value in the evaluation of services since service customers heavily based on the beliefs of other customers when creating an expectation about the service (Haywood, 1989). Therefore;

Hypothesis $5\left(\left(\mathrm{H}_{5}\right)\right)$. PWI is positively correlated with the Word of- mouth.

\subsubsection{The effect of PWI in hedonic value}

Values are not only principles or rules about some acceptable end-state of existence but also they are the means that people use to appraise events and actions (Rokeach, 1973). The value may be outward the experience helps the customer to reach some specific purpose. Moreover, it may be essential that the experience is enjoyed for its purpose (Batra \& Ahtola, 1991). Hence, individual hedonic values arise from a person inner self and it's not affected by other factors such as external pressure (Nguyen, Nguyen, \& Do, 2019). Meantime, Sheth, Newman, and Gross (1991) use the experiential value theory to describe why customers will remain to buy goods and classify experiential values into social, emotional, conditional, epistemic, and functional value. Despite this general conceptualization, some authorities propose that hedonic construct dimension of customer behavior toward buying intention purposes (Babin, Darden, \& Griffin, 1994; Voss, Spangenberg, \& Grohmann, 2003). Following Dhar and Wertenbroch (2000), hedonic value refers the pleasure being primary benefits of consumer cooperation in product or service. Therefore, we recommend that hedonic values of using e-retailer websites play major roles in consumers' continuation intention. Innovativeness is identified as the customers' decision-making style, including affective and cognitive dimensions of their rational orientations when making decisions (Sprotles \& Kendall, 1986). Prior researches have tried to estimate the effect of innovativeness on hedonic values. For example, surveys such as that accompanied by Kim, Fiore, Niehm, and Jeong (2010) have shown that customer innovativeness has not linked to but positively link to hedonism, and hedonic positively influence intention to patronize pop-up markets. In the same vein, Noh, Runyan, and Mosier (2014) mention that innovative young customers are likely to have a greater hedonic attitude toward great clothing than non-innovative young customers; inequality, there is no important relationship between hedonic values and innovativeness of great goods between young customers. Furthermore, empirical research by Hartman and Samra (2008) that analyses the effect of innovativeness on hedonic characters of web consumption behavior discovered that innovativeness is positively related to hedonic regarding web user behavior. Similarly, Lowe and Alpert (2015) also evaluate customers' overall innovativeness, rising from perceptions of technology newness, goods concept newness, and affecting customer hedonic values, and relative advantage. Therefore, this research investigates how customer innovativeness influences the experience of using e-retailers' websites and experiential value perception. Consequently, the following hypotheses are proposed:

Hypothesis $6\left(\left(\mathrm{H}_{6}\right)\right)$. PWI is positively correlated to the hedonic value.

\subsubsection{The effect of PWI in supply chain performance}

Innovation is crucial for firm sustainability (Drucker, 2002), therefore a firm in the fast-evolving knowledge-intensive service must give close consideration to e-retailer website innovation (Howells et al., 2004; Miles, 1995). Chapman, Soosay, and Kandampully (2003) recommend that the service industry requires a focus on supply chain innovation for efficient delivery of services, this study focused on e-retailer website innovativeness. Supply chain innovation has been viewed as a significant success factor for organizational as well as e-retailer website performance (Herzlinger, 2013; Schneller \& Smeltzer, 2006). Supply chain innovation relates to tools that can improve e-retailer website processes required for efficient supply chain management by seamless communications with suppliers, manufacturers, distributors, and consumers (Lin, 2008). Hence, supply chain innovation enables a reduction in cost and lead time, the creation of new operational strategies (Lee, Lee, \& Schniederjans, 2011), which will improve organizational overall performance (Khalil, Khalil, \& Khan, 2019), Thus, will reflects on the performance of e-retailers website innovation. Effective supply chain innovation offers quality services by guaranteeing continuous enhancement and overcoming service providing errors (Yoon, Lee, \& Schniederjans, 2016). Hence, supply chain innovation will help to guarantee the efficient supply of products and services through the eretailer website to buyers in the rapidly developing e-commerce markets. According to previous studies (Lundvall, Dosi, \& Freeman, 1988; Schneller \& Smeltzer, 2006; Sivadas \& Dwyer, 2000), the interaction between customers and retailers 
influence innovation, which involves changes or developments in the way of providing products, services or processes to reduce cost and/or improve efficiency (Abu-AlSondos \& Salameh, 2020). Hult, Hurley, and Knight (2004) discovered that within innovativeness, managers contrivance resolutions to business dilemmas and challenges, which present a basis for organization success into the prospect. Woodside (2005), to improve the outcomes by Hult et al. (2004), implies that the impact of innovativeness on business performance might be indirect. hence, based on this assumption, supply chain performance might be an essential variable that might influence an organization's competitive benefits and organization performance. Hult and Ketchen Jr (2001) tended that innovativeness gives to organization positional benefits and in turn competitive advantage. In these circumstances, it can be assumed that innovativeness impact supply chain performance positively. Based on the above argument researcher examine the hypothesis as follows:

Hypothesis $7\left(\left(\mathrm{H}_{7}\right)\right)$. PWI is positively correlated to supply chain performance.

\section{Research methodology}

\subsection{Sample of respondents}

In this research, the researchers utilized a quantitative approach during the examination process. This study was conducted at bank consumers who own visa card that allows them to make an online purchasing from an e-retailer website, provided by two private and one public bank, and the reason behind choosing the sample is that they are more able to conduct an online purchasing (Katawetawaraks \& Wang, 2011; Liao \& Cheung, 2001), this study utilizes (supply chain performance, functional competences, perceived self-congruence, customer hope, perceived service advantages, word of mouth behavior, and hedonic value) to meet the research goals. The data were obtained during 3 months starting from April 2020 to June 2020. A 5-point Likert scale was applied and the responses were divided from 1 ("strongly disagree") to 5 ("strongly agree"). As notified down next table 1 presents the measurement items utilized as a reference for that study.

Moreover, 246 questionnaires were distributed while 211 questionnaires were returned, and 43 were found unfinished. The rate of the respondents was $85.77 \%$ while the usable rate for the analysis of response was $68.29 \%$ just because only 168 surveys were utilized for the research.

\section{Analysis and findings}

\subsection{The validity and reliability of the model}

In this research, the researcher applied SEM-PLS, particularly SmartPLS 3 to evaluate the predictive importance of the conceptual framework, and whereby test the hypothesized relations as described in Fig. 1. The researcher preferred PLS for several reasons. PLS includes no conditional premises about the population or computing scale (Wold, 1982), hence According to Fornell and Bookstein (1982), the randomness and normality of the sample of the distribution of variables are not needed. An introductory analysis of this research showed that some signs were not regularly distributed and as such PLS is suitable for use in this research. Moreover, PLS concentrates on the description of variance utilizing least-square ordinal, this method is properly suited for the examination of associations in a predictive preferably a confirmatory fashion (Fornell \& Bookstein, 1982). in this research, the main affair is with maximizing the forecast of endogenous dependent constructs. Lastly, PLS has been extensively used in the marketing literature content (Kleijnen, De Ruyter, \& Wetzels, 2007; Slotegraaf \& Dickson, 2004). Utilizing a two-step analytic procedure related to that described by Chen, Meservy, and Gillenson (2012); Limayem and Cheung (2008), the psychometric ownership of the measurement framework was first estimated and verified and then the structural framework was estimated. Following the path of Ngo and O'Cass (2009), the researcher evaluated the sufficiency and significance of the outer-measurement framework and the predictive relevance of individual ways and the structural framework. The importance of a reflective outer-measurement framework for the extra constructs was estimated by an analysis of a variety of indicators including individual indicator loadings and weights, composite reliability, (AVE), bootstrap t-values (critical ratio statistic), discriminant validity and convergent validity. Moreover, the researcher assessed the significance of the reflective outer-measurement model by measuring bootstrapped $\mathrm{t}$-values. The bootstrapping process of sampling was used to determine the accuracy of the reflective outer-measurement framework. In this research, bootstrap t-values were calculated on the base of 200 bootstrapping runs. As displayed in Table 1, the reflective outer-measurement framework explained acceptable bootstrap critical ratios matching the supported benchmarks of $>1.96$. We evaluated convergent validity for the sufficiency of the outer-measurement framework by measuring composite reliability (Hulland, 1999). Outcomes of the examination for convergent validity assured that the outer-measurement framework and their first-order factors met Nunnally (1975) reliability criteria $>0.70$. As exhibited in Table 1, the composite reliabilities for all of the constructs extend from 0.71 to 0.93 . Thus, the constructs associated with outer-measurement models exhibited satisfactory convergent validity. The researcher estimated the discriminant validity of the constructs through 3 ways. 1st, Fornell and Larcker (1981) recommend the practice of AVE, which means that discriminant validity is displayed if the AVE square root is higher than all corresponding correlations. 
Table 1

Outer model validation

\begin{tabular}{|c|c|c|c|}
\hline Measurement items & Loading & $t$-Value & Source \\
\hline PERCEIVED WEBSITE INNOVATIVENESS (PWI) & CR: $0.93 \quad$ AVE $_{\mathrm{b}}: 0.82$ & & \multirow{4}{*}{$\begin{array}{l}\text { (Loiacono, Watson, } \\
\text { \& Goodhue, 2007) }\end{array}$} \\
\hline $\begin{array}{l}\text { The retailer's website offered unique features for customers that are different } \\
\text { from existing e-retailer websites }(P W I 1)\end{array}$ & 0.90 & 102.55 & \\
\hline The e-retailer website is highly innovative (PWI2) & 0.84 & 123.40 & \\
\hline The e-retailer website has innovative features $(P W I 3)$ & 0.87 & 77.25 & \\
\hline FUNCTIONAL COMPETENCE (FCI) & CR: $0.79 \quad \mathrm{AVE}_{\mathrm{b}}: 0.73$ & & \multirow{7}{*}{$\begin{array}{l}\text { (Ganesan, 1994; } \\
\text { Garbarino \& } \\
\text { Johnson, 1999) }\end{array}$} \\
\hline $\begin{array}{l}\text { This e-retailer website representative has been franking in dealing with us } \\
\text { (FC1) }\end{array}$ & 0.72 & 32.96 & \\
\hline Promises made by this e-retailer website representative are reliable $(F C 2)$ & 0.82 & 46.02 & \\
\hline $\begin{array}{l}\text { This e-retailer website representative is knowledgeable regarding products } \\
\text { offered }(F C 3)\end{array}$ & 0.86 & 25.43 & \\
\hline This e-retailer website doesn't make false claims (FC4) & 0.76 & 11.24 & \\
\hline $\begin{array}{l}\text { If a problem such as shipment delays arise, the e-retailer website representative } \\
\text { is honest about the problems }(F C 5)\end{array}$ & 0.90 & 61.82 & \\
\hline $\begin{array}{l}\text { This e-retailer website representative has problems answering our questions } \\
\text { (FC6) }\end{array}$ & 0.88 & 13.34 & \\
\hline PERCEIVED SELF-CONGRUENCE (PSC) & CR: $0.71 \quad \mathrm{AVE}_{\mathrm{b}}: 0.80$ & & \multirow{4}{*}{ (Sirgy et al., 1997) } \\
\hline $\begin{array}{l}\text { Selecting the required product from that e-retailer website is consistent with } \\
\text { how I see myself (PSC1) }\end{array}$ & 0.92 & 45.33 & \\
\hline $\begin{array}{l}\text { Selecting the required product from that e-retailer website reflects who I am } \\
\text { (PSC2) }\end{array}$ & 0.94 & 12.50 & \\
\hline $\begin{array}{l}\text { People similar to me purchase a product comparable to my preferences from an } \\
\text { e-retailer website (PSC3) }\end{array}$ & 0.85 & 56.09 & \\
\hline CUSTOMER HOPE (CH) & CR: $0.86 \quad \mathrm{AVE}_{\mathrm{b}}: 0.69$ & & \multirow{4}{*}{ (Snyder, 1995) } \\
\hline $\begin{array}{l}\text { I hope I can reach my goals concerning the products' I purchased through the } \\
\text { e-retailer website ( } \mathrm{CH} 1)\end{array}$ & 0.73 & 90.41 & \\
\hline $\begin{array}{l}\text { I hope that the products I purchased through the e-retailer website would } \\
\text { benefit me ( } \mathrm{CH} 2)\end{array}$ & 0.79 & 65.21 & \\
\hline $\begin{array}{l}\text { When purchasing a product through the e-retailer website, I am always hopeful } \\
\text { that I shall achieve what I looking for }(\mathrm{CH} 3)\end{array}$ & 0.70 & 106.17 & \\
\hline PERCEIVED SERVICE ADVANTAGE (PSA) & CR: $0.83 \quad \mathrm{AVE}_{\mathrm{b}}: 0.77$ & & \multirow{5}{*}{ (Kaleka, 2011) } \\
\hline $\begin{array}{l}\text { The e-retailer website offers various services compared with other stores } \\
\text { (PSA1) }\end{array}$ & 0.84 & 38.46 & \\
\hline $\begin{array}{l}\text { The e-retailer website offers better service quality compared with other stores } \\
(P S A 2)\end{array}$ & 0.95 & 97.56 & \\
\hline $\begin{array}{l}\text { The e-retailer website offers more innovative service products than other stores } \\
\text { (PSA3) }\end{array}$ & 0.90 & 69.51 & \\
\hline The e-retailer website offers more creative promotions than other stores (PSA4) & 0.81 & 87.23 & \\
\hline WORD OF MOUTH BEHAVIOR (WMB) & CR: $0.89 \quad \mathrm{AVE}_{\mathrm{b}}: 0.73$ & & \multirow{5}{*}{$\begin{array}{l}\text { (Bambauer-Sachse } \\
\text { \& Mangold, 2011; } \\
\text { Cheung \& Lee, } \\
\text { 2012) }\end{array}$} \\
\hline $\begin{array}{l}\text { To make sure that I buy the right products or brands, I often read online } \\
\text { reviews of products and brands written by other fellow members in social } \\
\text { networks about the e-retailer website }(W M B I)\end{array}$ & 0.94 & 154.97 & \\
\hline $\begin{array}{l}\text { To choose the right products or brands, I often consult online reviews of } \\
\text { products and brands provided by other fellow members in social networks } \\
\text { about the e-retailer website }(W M B 2)\end{array}$ & 0.91 & 112.80 & \\
\hline $\begin{array}{l}\text { I always publish my experiences with products and brands in social networks } \\
\text { on request of other members in the e-retailer website }(W M B 3)\end{array}$ & 0.84 & 73.68 & \\
\hline $\begin{array}{l}\text { I am willing to share my experiences with products and brands with other } \\
\text { fellow members in social networks in the e-retailer website (WMB4) }\end{array}$ & 0.89 & 186.60 & \\
\hline HEDONIC VALUE (HV) & CR: $0.81 \quad \mathrm{AVE}_{\mathrm{b}}: 0.63$ & & \multirow{5}{*}{$\begin{array}{l}\text { (Moon \& Kim, } \\
\text { 2001) }\end{array}$} \\
\hline Using an e-retailer website gives fun to me (HVI) & 0.71 & 17.66 & \\
\hline Using an e-retailer website keeps me happy $(H V 2)$ & 0.78 & 14.50 & \\
\hline Using an e-retailer website gives enjoyment to me (HV3) & 0.76 & 21.95 & \\
\hline Using an e-retailer website stimulates my curiosity (HV4) & 0.86 & 12.56 & \\
\hline SUPPLY CHAIN PERFORMANCE (SCP) & CR: $0.91 \quad \mathrm{AVE}_{\mathrm{b}}: 0.86$ & & \multirow{8}{*}{$\begin{array}{l}\text { (Panayides \& Lun, } \\
\text { 2009) }\end{array}$} \\
\hline Delivery reliability $(S C P 1)$ & 0.87 & 89.21 & \\
\hline Responsiveness (SCP2) & 0.82 & 106.35 & \\
\hline Cost reduction ( $S C P 3)$ & 0.91 & 220.83 & \\
\hline Lead times $(S C P 4)$ & 0.95 & 196.50 & \\
\hline Conformance to specifications (SCP5) & 0.84 & 97.90 & \\
\hline Process improvement (SCP6) & 0.80 & 147.60 & \\
\hline Time-to-market (SCP7) & 0.93 & 113.24 & \\
\hline
\end{tabular}


As exhibited in Table 2, the AVE square roots values are consistently higher than the off-diagonal correlations, implying discriminant validity at the level of construct. 2nd, Gaski and Nevin (1985) propose that satisfactory discriminant validity between constructs is taken when the association between two composite constructs is not greater than their respective reliability ratings. As satisfactory discriminant validity, the in-bracket diagonal entries must be greater than the off-diagonal entries in the corresponding columns and rows. An analysis of Table 2 shows that no individual associations (ranged from 0.11 to 0.72 ) were greater than their respective reliabilities (ranged from 0.75 to 0.96 ), hence showing satisfactory discriminant validity of all constructs. Lastly, all constructs present discriminant validity if each correlation is smaller than one by a sum larger than twice its respective standard error (Bagozzi \& Warshaw, 1990). An analysis of the standard error using PLS bootstrap outputs shows that all constructs pass this third test. Therefore, adequate discriminant validity is being for all constructs. The outcomes are presented in Tables 1 and 2 include adequate psychometric characteristics of the outer framework to move to an evaluation of the structural framework to examine the hypotheses.

Table 2

Discriminate validity and correlations among constructs.

\begin{tabular}{|c|c|c|c|c|c|c|c|c|c|c|}
\hline Construct & Mean & $\mathrm{SD}$ & 1 & 2 & 3 & 4 & 5 & 6 & 7 & 8 \\
\hline 1. Perceived website Innovativeness & 5.44 & 1.79 & 0.85 & & & & & & & \\
\hline Functional competence & 6.01 & 1.24 & 0.41 & 0.75 & & & & & & \\
\hline Perceived self-congruence & 4.30 & 0.88 & 0.55 & 0.21 & 0.91 & & & & & \\
\hline 4. Customer hope & 5.67 & 1.13 & 0.46 & 0.36 & 0.23 & 0.80 & & & & \\
\hline Perceived service advantage & 4.12 & 1.66 & 0.12 & 0.59 & 0.62 & 0.41 & 0.87 & & & \\
\hline Word of mouth behavior & 5.09 & 1.38 & 0.39 & 0.27 & 0.44 & 0.11 & 0.66 & 0.96 & & \\
\hline 7. Hedonic value & 4.89 & 0.86 & 0.68 & 0.19 & 0.28 & 0.47 & 0.45 & 0.39 & 0.92 & \\
\hline 8. Supply chain performance & 6.21 & 1.92 & 0.72 & 0.33 & 0.15 & 0.38 & 0.16 & 0.23 & 0.61 & 0.94 \\
\hline
\end{tabular}

\subsection{Hypotheses testing procedures}

The hypothesized relationships of the framework as mentioned in Fig. 1. was tested by conducting the PLS algorithm following performing the required procedures. In this study, (PLS-SEM) was conducted by the researchers as the main analysis method due to the multivariate regularity assumption of the data was not satisfied. Thus, the hypothesized relationships were tested verifying the reliability and validity of the framework measurement. The structural framework was investigated and the outcomes were described in detail (mentioned in Table 3).

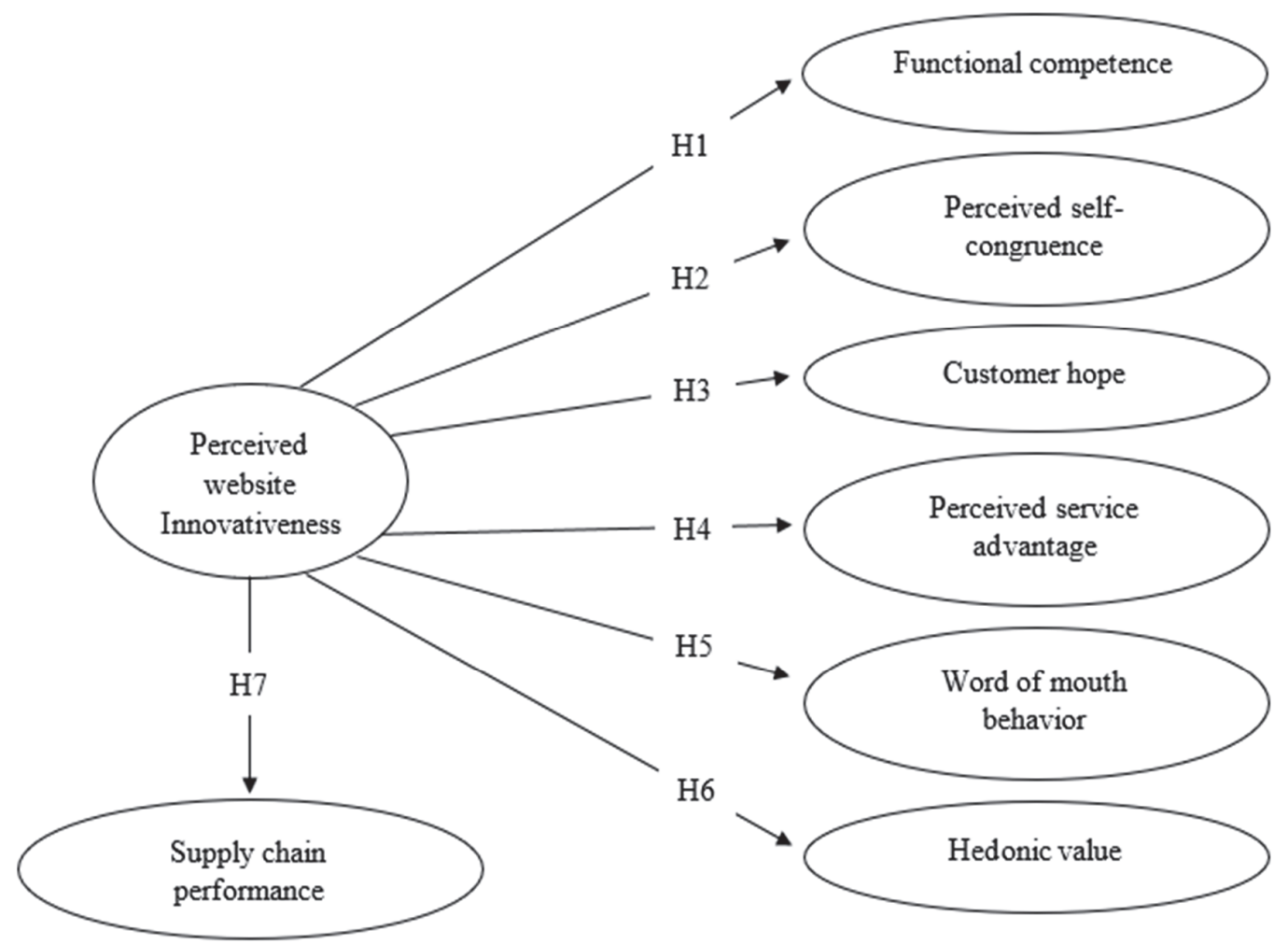

Fig. 1. Research model 
Table 3

Summary outcomes

\begin{tabular}{clc}
\hline Hypothesis & Hypothesized path & Decision \\
\hline H1 & PWI is positively correlated to functional competence. & Supported \\
H2 & PWI is positively correlated to the perceived self-congruence. & Supported \\
H3 & PWI is positively correlated to the customer hope in online purchases. & Supported \\
H4 & PWI is positively correlated to the perceived service advantage. & Supported \\
H5 & PWI is positively correlated to the Word of- mouth. & Supported \\
H6 & PWI is positively correlated to the hedonic value. & Supported \\
H7 & PWI is positively correlated to supply chain performance. & Supported \\
\hline
\end{tabular}

\section{Future direction}

To get a better understanding of an individual's receptivity to the e-retailer website, this study suggests that future researchers to examine more variables such as costumers' openness to information which may explain how specific types of purchasers may be more receptive to innovative e-retail context. Moreover, the researchers may also examine customer emotional satisfaction, website loyalty, payment of private information. Accordingly, the examination of these relevant variables construct in future studies will permit a deeper understanding of the formation of buyer perceptions of e-retailers' website innovativeness.

Additionally, from the perspective of marketing, a future study can use conjoint analysis to discover how customers value various attributes (feature, function, interests) of e-retailers' websites to understand customer preferences.

\section{Discussion and conclusion}

The value of this study arises from the scarcity of multidisciplinary research. Despite the practical and theoretical necessity for relevant multidisciplinary studies, supply chain performance and e-retailer websites' innovation persist two primary streams of research with limited communication. Some studies (e.g. Lo \& Power, 2010; Pero et al., 2010) present useful insights within the alliance between e-retailer website innovation and supply chain design. Furthermore, this paper is one of the scarcity studies that attempts to incorporate the dimensions of both product and process innovation.

To classify factors that will enhance e-retailer website performance by supply chain performance, this investigation stated a research framework that involves the relationships among functional competences, perceived self-congruence, customer hope, perceived service advantages, word of mouth behavior, hedonic value. Data were obtained from banking customers who own a visa card that allows them an online payment to test 7 hypotheses in the model. Our study not only exposes how e-retailers website innovation influences the 7 dimensions that the paper examines, but it also points out that e-retailer website innovative performance exerts a direct relationship role towards supply chain performance.

\section{Acknowledgment}

The researcher extends his sincere thanks to the Deanship of Scientific Research at Prince Sattam Bin Abdulaziz University for its continuous support and contributions in the field of scientific research.

\section{References}

Abu-AlSondos, I. A., \& Salameh, A. A. M. (2020). The effect of system quality and service quality toward using mcommerce service, based on consumer perspective. Management Science Letters, 10(11), 2589-2596.

Alalwan, A. A., Baabdullah, A. M., Rana, N. P., Tamilmani, K., \& Dwivedi, Y. K. (2018). Examining adoption of mobile internet in Saudi Arabia: Extending TAM with perceived enjoyment, innovativeness and trust. Technology in Society, $55,100-110$.

Alexander, L., \& Van Knippenberg, D. (2014). Teams in pursuit of radical innovation: A goal orientation perspective. Academy of Management Review, 39(4), 423-438.

Alkafagi, A., Salameh, A. A. M., \& Abu-AlSondos, I. A. (2019). The importance of individual technology factors for adoption of internet banking. European Journal of Business and Management, 11(36), 1-8. doi:10.7176/EJBM/11-3601

Arlbjørn, J. S., de Haas, H., \& Munksgaard, K. B. (2011). Exploring supply chain innovation. Logistics research, 3(1), 318.

Arlbjørn, J. S., \& Paulraj, A. (2013). Special topic forum on innovation in business networks from a supply chain perspective: current status and opportunities for future research. Journal of Supply Chain Management, 49(4), 3-11.

Babin, B. J., Darden, W. R., \& Griffin, M. (1994). Work and/or fun: measuring hedonic and utilitarian shopping value. Journal of Consumer Research, 20(4), 644-656. 
Bagozzi, R. P., \& Warshaw, P. R. (1990). Trying to consume. Journal of Consumer Research, 17(2), 127-140.

Bambauer-Sachse, S., \& Mangold, S. (2011). Brand equity dilution through negative online word-of-mouth communication. Journal of Retailing and Consumer Services, 18(1), 38-45.

Batra, R., \& Ahtola, O. T. (1991). Measuring the hedonic and utilitarian sources of consumer attitudes. Marketing Letters, 2(2), 159-170.

Bellamy, M. A., Ghosh, S., \& Hora, M. (2014). The influence of supply network structure on firm innovation. Journal of Operations Management, 32(6), 357-373.

Blackhurst, J., Wu, T., \& O'Grady, P. (2005). PCDM: a decision support modeling methodology for supply chain, product and process design decisions. Journal of Operations Management, 23(3-4), 325-343.

Brown, T. J., \& Dacin, P. A. (1997). The company and the product: Corporate associations and consumer product responses. Journal of Marketing, 61(1), 68-84.

Burgess, T. F., \& Gules, H. K. (1998). Buyer-supplier relationships in firms adopting advanced manufacturing technology: an empirical analysis of the implementation of hard and soft technologies. Journal of Engineering and Technology Management, 15(2-3), 127-152.

Castaño, R., Sujan, M., Kacker, M., \& Sujan, H. (2008). Managing consumer uncertainty in the adoption of new products: Temporal distance and mental simulation. Journal of Marketing Research, 45(3), 320-336.

Chapman, R. L., Soosay, C., \& Kandampully, J. (2003). Innovation in logistic services and the new business model. International Journal of Physical Distribution \& Logistics Management.

Chen, L., Meservy, T. O., \& Gillenson, M. (2012). Understanding information systems continuance for information-oriented mobile applications. Communications of the Association for Information Systems, 30(1), 9.

Cheung, C. M., \& Lee, M. K. (2012). What drives consumers to spread electronic word of mouth in online consumeropinion platforms. Decision Support Systems, 53(1), 218-225.

Cho, Y. K., \& Menor, L. J. (2010). Toward a provider-based view on the design and delivery of quality e-service encounters. Journal of Service Research, 13(1), 83-95.

Chou, Y.-C., Chuang, H. H.-C., \& Shao, B. B. (2016). The impact of e-retail characteristics on initiating mobile retail services: A modular innovation perspective. Information \& Management, 53(4), 481-492.

Cialdini, R. B. (1984). The psychology of persuasion. New York: Quill William Morrow.

Colton, D. A. (2012). The role of retailer mindset and promotional resources in strengthening online brands. Journal of Brand Management, 20(1), 28-40.

Crippa, R., Larghi, L., Pero, M., \& Sianesi, A. (2010). The impact of new product introduction on supply chain ability to match supply and demand. International Journal of Engineering, Science and Technology, 2(9).

Danneels, E., \& Kleinschmidtb, E. J. (2001). Product innovativeness from the firm's perspective: Its dimensions and their relation with project selection and performance. Journal of Product Innovation Management: An International Publication of the Product Development \& Management Association, 18(6), 357-373.

Davis, A., \& Khazanchi, D. (2008). An empirical study of online word of mouth as a predictor for multi-product category e-commerce sales. Electronic Markets, 18(2), 130-141.

Davis, R., Buchanan-Oliver, M., \& Brodie, R. J. (2000). Retail service branding in electronic-commerce environments. Journal of Service Research, 3(2), 178-186.

Day, G. S. (1971). Attitude change, media and word of mouth. Journal of advertising research.

Dhar, R., \& Wertenbroch, K. (2000). Consumer choice between hedonic and utilitarian goods. Journal of Marketing Research, 37(1), 60-71.

Dougherty, D. (1992). Interpretive barriers to successful product innovation in large firms. Organization Science, 3(2), 179202.

Drucker, P. F. (2002). The discipline of innovation. Harvard Business Review, 80, 95-104.

Fazal-e-Hasan, S. M., Ahmadi, H., Kelly, L., \& Lings, I. N. (2019). The role of brand innovativeness and customer hope in developing online repurchase intentions. Journal of Brand Management, 26(2), 85-98.

Fisher, M. L. (1997). What is the right supply chain for your product? Harvard business review, 75, 105-117.

Fornell, C., \& Bookstein, F. L. (1982). Two structural equation models: LISREL and PLS applied to consumer exit-voice theory. Journal of Marketing Research, 19(4), 440-452.

Fornell, C., \& Larcker, D. F. (1981). Evaluating structural equation models with unobservable variables and measurement error. Journal of Marketing Research, 18(1), 39-50.

Fournier, S., \& Alvarez, C. (2013). Relating badly to brands. Journal of Consumer Psychology, 23(2), 253-264.

Fu, F. Q., \& Elliott, M. T. (2013). The moderating effect of perceived product innovativeness and product knowledge on new product adoption: An integrated model. Journal of Marketing Theory and Practice, 21(3), 257-272.

Gabdullina, L., Amanbayeva, A., Zeinullina, A., Tlessova, E., \& Azylkanova, S. (2020). Transport and logistics innovations in supply chain management: Evidence from Kazakhstan. Uncertain Supply Chain Management, 8(2), 255-266.

Gan, T.-S., \& Grunow, M. (2013). Concurrent product-supply chain design: a conceptual framework \& literature review. Procedia CIRP, 7(1), 91-96.

Ganesan, S. (1994). Determinants of long-term orientation in buyer-seller relationships. Journal of Marketing, 58(2), 1-19.

Garbarino, E., \& Johnson, M. S. (1999). The different roles of satisfaction, trust, and commitment in customer relationships. Journal of marketing, 63(2), 70-87.

Gaski, J. F., \& Nevin, J. R. (1985). The differential effects of exercised and unexercised power sources in a marketing channel. Journal of Marketing Research, 22(2), 130-142. 
Gerpott, T. J., \& Meinert, P. (2016). The impact of mobile Internet usage on mobile voice calling behavior: A two-level analysis of residential mobile communications customers in Germany. Telecommunications Policy, 40(1), 62-76.

Godes, D., \& Mayzlin, D. (2004). Using online conversations to study word-of-mouth communication. Marketing Science, 23(4), 545-560.

Gürhan-Canli, Z., \& Batra, R. (2004). When corporate image affects product evaluations: The moderating role of perceived risk. Journal of Marketing Research, 41(2), 197-205.

Hartman, J. B., \& Samra, Y. M. (2008). Impact of personal values and innovativeness on hedonic and utilitarian aspects of web use: An empirical study among United States teenagers. International Journal of Management, 25(1), 77.

Hausman, A. V., \& Siekpe, J. S. (2009). The effect of web interface features on consumer online purchase intentions. Journal of Business Research, 62(1), 5-13.

Haywood, K. M. (1989). Managing word of mouth communications. Journal of Services Marketing.

Herzlinger, R. E. (2013). Innovating in Health Care-Framework.

Hoeffler, S. (2003). Measuring preferences for really new products. Journal of Marketing Research, 40(4), 406-420.

Holahan, P. J., Sullivan, Z. Z., \& Markham, S. K. (2014). Product development as core competence: How formal product development practices differ for radical, more innovative, and incremental product innovations. Journal of Product Innovation Management, 31(2), 329-345.

Hong, J.-C., Lin, P.-H., \& Hsieh, P.-C. (2017). The effect of consumer innovativeness on perceived value and continuance intention to use smartwatch. Computers in Human Behavior, 67, 264-272.

Howells, J., Tether, B., Gallouj, F., Djellal, F., Gallouj, C., Blind, K., . . Corrocher, N. (2004). Innovation in Services: Issues at Stake and Trends.

Hulland, J. (1999). Use of partial least squares (PLS) in strategic management research: A review of four recent studies. Strategic Management Journal, 20(2), 195-204.

Hult, G. T. M., Hurley, R. F., \& Knight, G. A. (2004). Innovativeness: Its antecedents and impact on business performance. Industrial Marketing Management, 33(5), 429-438.

Hult, G. T. M., \& Ketchen Jr, D. J. (2001). Does market orientation matter?: A test of the relationship between positional advantage and performance. Strategic Management Journal, 22(9), 899-906.

Kaleka, A. (2011). When exporting manufacturers compete on the basis of service: Resources and marketing capabilities driving service advantage and performance. Journal of International Marketing, 19(1), 40-58.

Kang, J., Tang, L., \& Lee, J. Y. (2015). Self-congruity and functional congruity in brand loyalty. Journal of Hospitality \& Tourism Research, 39(1), 105-131.

Katawetawaraks, C., \& Wang, C. (2011). Online shopper behavior: Influences of online shopping decision. Asian Journal of Business Research, 1(2).

Khalil, M., Khalil, R., \& Khan, S. (2019). A study on the effect of supply chain management practices on organizational performance with the mediating role of innovation in SMEs. Uncertain Supply Chain Management, 7(2), 179-190.

Kim, H., Fiore, A. M., Niehm, L. S., \& Jeong, M. (2010). Psychographic characteristics affecting behavioral intentions towards pop-up retail. International Journal of Retail \& Distribution Management.

Kleijnen, M., De Ruyter, K., \& Wetzels, M. (2007). An assessment of value creation in mobile service delivery and the moderating role of time consciousness. Journal of Retailing, 83(1), 33-46.

Kolesar, M. B., \& Galbraith, R. W. (2000). A services-marketing perspective on e-retailing: implications for e-retailers and directions for further research. Internet Research, 10(5), 424-438.

Kunz, W., Schmitt, B., \& Meyer, A. (2011). How does perceived firm innovativeness affect the consumer? Journal of Business Research, 64(8), 816-822.

Laukkanen, T. (2016). Consumer adoption versus rejection decisions in seemingly similar service innovations: The case of the Internet and mobile banking. Journal of Business Research, 69(7), 2432-2439.

Lee, J., Park, D. H., \& Han, I. (2011). The different effects of online consumer reviews on consumers' purchase intentions depending on trust in online shopping malls. Internet research.

Lee, S. M., Lee, D., \& Schniederjans, M. J. (2011). Supply chain innovation and organizational performance in the healthcare industry. International Journal of Operations \& Production Management.

Liao, Z., \& Cheung, M. T. (2001). Internet-based e-shopping and consumer attitudes: an empirical study. Information \& Management, 38(5), 299-306.

Limayem, M., \& Cheung, C. M. (2008). Understanding information systems continuance: The case of Internet-based learning technologies. Information \& Management, 45(4), 227-232.

Lin, C.-Y. (2008). Determinants of the adoption of technological innovations by logistics service providers in China. International Journal of Technology Management \& Sustainable Development, 7(1), 19-38.

Loiacono, E. T., Watson, R. T., \& Goodhue, D. L. (2007). WebQual: An instrument for consumer evaluation of web sites. International Journal of Electronic Commerce, 11(3), 51-87.

Lowe, B., \& Alpert, F. (2015). Forecasting consumer perception of innovativeness. Technovation, 45, 1-14.

Lundvall, B.-A., Dosi, G., \& Freeman, C. (1988). Innovation as an interactive process: from user-producer interaction to the national system of innovation. 1988, 349-369.

Lusch, R. F., Vargo, S. L., \& O’brien, M. (2007). Competing through service: Insights from service-dominant logic. Journal of Retailing, 83(1), 5-18. 
Marsillac, E., \& Roh, J. J. (2014). Connecting product design, process and supply chain decisions to strengthen global supply chain capabilities. International Journal of Production Economics, 147, 317-329.

Miles, I. (1995). Innovation in services. Chapters.

Moon, J.-W., \& Kim, Y.-G. (2001). Extending the TAM for a World-Wide-Web context. Information \& Management, $38(4), 217-230$.

Ngo, L. V., \& O'Cass, A. (2009). Creating value offerings via operant resource-based capabilities. Industrial Marketing Management, 38(1), 45-59.

Nguyen, T., Nguyen, K., \& Do, T. (2019). Knowledge sharing and innovative work behavior: The case of Vietnam. Uncertain Supply Chain Management, 7(4), 619-634.

Niedrich, R. W., \& Swain, S. D. (2003). The influence of pioneer status and experience order on consumer brand preference: A mediated-effects model. Journal of the Academy of Marketing Science, 31(4), 468-480.

Noh, M., Runyan, R., \& Mosier, J. (2014). Young consumers' innovativeness and hedonic/utilitarian cool attitudes. International Journal of Retail \& Distribution Management.

Nunnally, J. C. (1975). Psychometric theory-25 years ago and now. Educational Researcher, 4(10), 7-21.

Olson, J. C. (1977). Price as an Informational Cue: Effects on Product Evaluations. Consumer and Industrial Buying Behavior, Arch G. Woodside, Jagdish N. Sheth, and Peter D. Bennett, eds. In: Amsterdam: North-Holland Publishing Company.

Panayides, P. M., \& Lun, Y. V. (2009). The impact of trust on innovativeness and supply chain performance. International Journal of Production Economics, 122(1), 35-46.

Payne, T., \& Peters, M. J. (2004). What is the right supply chain for your products? The International Journal of Logistics Management, 15(2), 77-92.

Perry-Smith, J. E., \& Mannucci, P. V. (2017). From creativity to innovation: The social network drivers of the four phases of the idea journey. Academy of Management Review, 42(1), 53-79.

Petty, R. E., \& Cacioppo, J. T. (1996). Attitudes and persuasion: Classic and contemporary approaches: Westview Press.

Petty, R. E., \& Cacioppo, J. T. (2012). Communication and persuasion: Central and peripheral routes to attitude change: Springer Science \& Business Media.

Rana, N. P., Dwivedi, Y. K., Williams, M. D., \& Weerakkody, V. (2016). Adoption of online public grievance redressal system in India: Toward developing a unified view. Computers in Human Behavior, 59, 265-282.

Rogers, E. M., \& Shoemaker, F. F. (1971). Communication of Innovations; A Cross-Cultural Approach.

Rokeach, M. (1973). The nature of human values: Free press.

Roseman, I. J., Spindel, M. S., \& Jose, P. E. (1990). Appraisals of emotion-eliciting events: Testing a theory of discrete emotions. Journal of Personality and Social Psychology, 59(5), 899.

Rosqvist, L. S., \& Hiselius, L. W. (2016). Online shopping habits and the potential for reductions in carbon dioxide emissions from passenger transport. Journal of Cleaner Production, 131, 163-169.

Salameh, A. A. M., Ahmad, H., Zulhumadi, F., \& Abubakar, F. M. (2018). Relationships between system quality, service quality, and customer satisfaction. Journal of Systems and Information Technology, 20(1), 73-102.

Salameh, A. A. M., \& Hassan, S. B. (2015). Measuring service quality in m-commerce context: A conceptual model. International Journal of Scientific and Research Publications, 5(3), 1-9.

Schmitt, B. (1999). Experiential marketing. Journal of Marketing Management, 15(1-3), 53-67.

Schmitt, B., Brakus, J. J., \& Zarantonello, L. (2015). From experiential psychology to consumer experience. Journal of Consumer Psychology, 25(1), 166-171.

Schneller, E. S., \& Smeltzer, L. R. (2006). Strategic management of the health care supply chain: Jossey-bass.

Shams, R., Alpert, F., \& Brown, M. (2015). Consumer perceived brand innovativeness. European Journal of Marketing.

Shareef, M. A., Baabdullah, A., Dutta, S., Kumar, V., \& Dwivedi, Y. K. (2018). Consumer adoption of mobile banking services: An empirical examination of factors according to adoption stages. Journal of Retailing and Consumer Services, 43, 54-67.

Sheth, J. N., Newman, B. I., \& Gross, B. L. (1991). Why we buy what we buy: A theory of consumption values. Journal of Business Research, 22(2), 159-170.

Sirgy, M. J., Grewal, D., Mangleburg, T. F., Park, J.-o., Chon, K.-S., Claiborne, C. B., . . Berkman, H. (1997). Assessing the predictive validity of two methods of measuring self-image congruence. Journal of the Academy of Marketing science, 25(3), 229.

Sirgy, M. J., \& Su, C. (2000). Destination image, self-congruity, and travel behavior: Toward an integrative model. Journal of Travel Research, 38(4), 340-352.

Sivadas, E., \& Dwyer, F. R. (2000). An examination of organizational factors influencing new product success in internal and alliance-based processes. Journal of Marketing, 64(1), 31-49.

Slotegraaf, R. J., \& Dickson, P. R. (2004). The paradox of a marketing planning capability. Journal of the Academy of Marketing Science, 32(4), 371-385.

Snyder, C. R. (1995). Conceptualizing, measuring, and nurturing hope. Journal of Counseling \& Development, 73(3), $355-$ 360.

Sprotles, G. B., \& Kendall, E. L. (1986). A methodology for profiling consumers' decision-making styles. Journal of Consumer Affairs, 20(2), 267-279.

Vincent, L. H., Bharadwaj, S. G., \& Challagalla, G. N. (2004). Does innovation mediate firm performance?: a meta-analysis of determinants and consequences of organizational innovation. 
Voss, K. E., Spangenberg, E. R., \& Grohmann, B. (2003). Measuring the hedonic and utilitarian dimensions of consumer attitude. Journal of Marketing Research, 40(3), 310-320.

Walsh, G., \& Beatty, S. E. (2007). Measuring customer-based corporate reputation: scale development, validation, and application. Journal of the Academy of Marketing Science, 35(1), 127-143.

Wold, H. (1982). Soft modeling: The basic design and some extensions, systems under indirect observations. Causality. Structure. Prediction. Ed. KG Joreskog. H. Wold. Amsterdam: North Holland Publishing Company.

Woodside, A. G. (2005). Firm orientations, innovativeness, and business performance: Advancing a system dynamics view following a comment on Hult, Hurley, and Knight's 2004 study. Industrial Marketing Management, 34(3), $275-279$.

Xu, X., Thong, J. Y., \& Tam, K. Y. (2017). Winning back technology disadopters: testing a technology readoption model in the context of mobile internet services. Journal of Management Information Systems, 34(1), 102-140.

Yoon, S. N., Lee, D., \& Schniederjans, M. (2016). Effects of innovation leadership and supply chain innovation on supply chain efficiency: Focusing on hospital size. Technological Forecasting and Social Change, 113, 412-421.

Zeithaml, V. A., Berry, L. L., \& Parasuraman, A. (1996). The behavioral consequences of service quality. Journal of Marketing, 60(2), 31-46.

Zimmermann, R., Ferreira, L. M. D., \& Moreira, A. C. (2016). The influence of supply chain on the innovation process: a systematic literature review. Supply Chain Management: An International Journal.

Zinkhan, G. M., Ganesh, J., Jaju, A., \& Hayes, L. (2001). Corporate image: a conceptual framework for strategic planning. Paper presented at the American Marketing Association. Conference Proceedings.

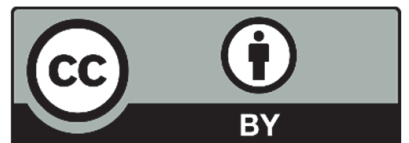

(C) 2020 by the authors; licensee Growing Science, Canada. This is an open access article distributed under the terms and conditions of the Creative Commons Attribution (CC-BY) license (http://creativecommons.org/licenses/by/4.0/). 